\title{
Insulin-resistance syndrome type B
}

INSERM

\section{Source}

INSERM. (1999). Orphanet: an online rare disease and orphan drug data base. Insulinresistance syndrome type B. ORPHA:2298

Type B insulin-resistance syndrome belongs to the group of extreme insulin-resistance syndromes (which includes leprechaunism, the lipodystrophies, Rabson-Mendenhall syndrome, and type A insulin resistance syndrome; see these terms) and occurs in the context of immune dysfunction. 